\title{
ENGLISH TEACHER' STRATEGY IN TEACHING LISTENING SECTION OF TOEFL PREPARATIONS
}

(Case Study at TOEFL Preparation class in English First Course Cilegon)

\author{
Wahhab Abdul Khobir ${ }^{1}$, Aa Qona'atun ${ }^{2}$ \\ University of Banten Jaya \\ Serang, Indonesia \\ Wahabaka31@gmail.com \\ aaqonaatun@unbaja.ac.id
}

\begin{abstract}
This research was intended to describe the strategies used by the teacher in teaching TOEFL preparation to support the students especially listening skill, the steps the teacher to implementing the strategies teacher, and the problem faced in enhancement 25\% listening score in listening skill. This methodology was qualitative research with case study, the subject of the research was English teacher TOEFL preparation in EF Course Cilegon. The collecting data of this research used data display, data reduction and conclusion focus this research is strategies in teaching listening section in TOEFL and sub focus are direct and indirect in teaching listening section in TOEFL Preparation. The result strategies of this research are used simulation, discussions, giving tips and tricks, the course used ICT modern era, games, and motivation, the conclusion is There are some statements for the student participant about teacher strategies in teaching TOEFL Preparation. They are: First, teacher strategies can improve confidence in good speaker and listener. Second, teacher strategies can make students feel easier to take exam TOEFL. Third, the student often listening native speakers to understand can be enhanced. Fourth, the student can be more active how take TOEFL be well. the last, the student knows how to know type question in TOEFL especially listening section of the strategies. The writer found sixth strategies used by the EF Cilegon to teach TOEFL Preparation especially listening section.
\end{abstract}

Keywords: Teacher strategy, TOEFL Preparation, Teaching

\section{INTRODUCTION}

Based on Cambridge University Press; 3 edition (March 11, 2008) TOEFL ("Test of English as a Foreign Language") is an examination that is administered by the educational testing services (ETS) and is used to evaluate a nonnative English speaker's proficiency in the English language. The type of TOEFL are PBT (Paper Based Test), CBT (Computer based tets), IBT (Internet based test), TOEFL like, and TOEFL ITP (Institutional testing program) The tests are used for some purposes. In Indonesia, these test is required in some institutions, such as universities, government institutions or international companies. According TOEFL Program History since its initial launch in 1964, the TOEFL test has undergone several major revisions motivated by advances in theories of language ability and changes in English teaching practices. The most recent revision TOEFL test. Since the 1970s, the TOEFL test has had a rigorous, productive, and far-ranging study program. But why should test score users care about the study base for a test, In short, it is only through a rigorous program of study that a 
testing company can substantiate claims about what test takers know or can do based on their test scores, as well as provide support for the intended uses of assessments

TOEFL is also requirements to apply for scholarships for students who want to continue their study in either Indonesia or abroad. Scholarships such as the Australia Awards Scholarship (AAS), USAID (the United States Agency for International Development) Prestasi, LPDP (Indonesia Endowment Fund for Education) oblige the applicants to have English language proficiency, so they can send the applicants to school abroad. Because of these reasons, it can be understood that English language proficiency tests are important to pursue a career and earn a university degree. Their use as a requirement for university entry and scholarship, TOEFL is viewed as the factors of international recognition rather than as an assessment of one's ability in communication (Khan, 2009). It is because those tests are biased towards the inner circle countries such as the UK, USA, Australia and Canada, they are not appropriate in the local context. Hence, the non-native English speakers find it quite difficult to comprehend the discourse.

Table 1. Range Comparison IBT, CBT, And PBT Source: Cambridge Preparation for TOEFL Test $4^{\text {th }}$ Edition page ii

\begin{tabular}{|ccc}
\hline $\begin{array}{c}\text { Internet- } \\
\text { based Total }\end{array}$ & $\begin{array}{c}\text { Computer- } \\
\text { based Total }\end{array}$ & $\begin{array}{c}\text { Paper-based } \\
\text { Total }\end{array}$ \\
\hline $112-120$ & $273-300$ & $640-677$ \\
\hline $96-110$ & $243-270$ & $590-637$ \\
\hline $79-95$ & $213-240$ & $550-587$ \\
\hline $65-78$ & $183-210$ & $513-547$ \\
\hline $53-64$ & $153-180$ & $477-510$ \\
\hline $41-52$ & $123-150$ & $437-473$ \\
\hline $30-40$ & $93-120$ & $397-433$ \\
\hline $19-29$ & $63-90$ & $347-393$ \\
\hline $9-18$ & $33-60$ & $310-343$ \\
\hline $0-8$ & $0-30$ & 310 \\
\hline In other hand & according to & Bryson \\
\hline
\end{tabular}

(2004), a strategy is defined as a pattern, of purpose, policies, program, actions, decisions, or resource allocations that define what an organization is, what it does, and why it does it, these explanations give the meaning of strategies give the meaning of strategy as the step to decide what will do in an activity. Furthermore, a strategy used in teaching (teaching strategy) that is mentioned buy Smith in Aggrawal (2014). Refers to a pattern of teaching acts that serve to attain certain outcomes.

\section{According to Rebecca L Oxford} (1990) language learning strategies that directly involve the target language are called direct strategies and indirect strategies divide into metacognitive, affective and social. Metacognitive strategies allow learners to control their own cognition that is to coordinate the learning process by using a function such as 
centering, arranging, planning, and evaluating.

Teaching in EF Course, be teaching people who live just down the street, giving the unique chance to bring them an international experience just outside their door. English First so that focuses on offering the best language journey for both kids and adults. the lessons take place inside real classrooms with amazing teacher resources. The student has a variety of classes including face-to-face small lessons, large workshops and Life Clubs, EF's very own course that encourages students to apply their language learning skills in a social environment. Learn about EF Course and what makes us special by seeing what makes us the ESL experts.

Based on pre-observation on 3 February 2020, the writer interviewed Mr. Kaisan as a teacher EF. He has been dealt with professional, friendly and supportive manner. and fun in class, are very polite and a pleasure to teach, teaching TOEFL Preparation with EF Course at the same time using technology teaching in TOEFL Preparation. The teacher will have the opportunity to work with people from different countries and be a part of a global company that wants to "open the world through education" and EF Teacher using ICT Program EF Course Cilegon are first is Teaching Listening of second language is not derived naturally; it needs some processes of learning. The second $\mathrm{Mr}$. Kaisan explain about Audio Video, according Harmer (2007: 144) explains that using video can be much richer than using audio.

The teacher giving the students long terms videos may trap them in unexpected situation like uncritically and lazily and just enjoy the story in the video like they always do when they watch film or movie at home. Harmer (2007: 144) has warned about the danger of videos. The students may treat them rather as they treat watching television, uncritically and lazily, on the other hand teachers want them to engage; not only the content of what they are seeing but also other language features. The writer found A significant increase of $25 \%$ during preparation up to the test.

\section{METHOD}

In this study focus on the teacher's strategies in teaching TOEFL Preparations, especially on the teacher strategies in listening skill was used by the English teacher in English First Course at Cilegon City, And sub focus are direct strategies in listening of TOEFL Preparation and Indirect strategies in listening of TOEFL Preparation at EF Course Cilegon.

This study use descriptive qualitative in the form of a case study which used observation to collect the data; the observe the strategies employed by the 
tutor in teaching TOEFL Preparation. The study to start from December 2019 - May 2020 and interview to teacher (Mr. Kaisan). In this study was conducted in English First Course at Cilegon City. In analyzing the data be the writer was use matrix description of Miles and Huberman. This includes data reduction, data display, and conclusion drawing verification.

\section{DISCUSSION}

The presentation of the data findings in this part, related to the teacher's strategies in teaching TOEFL Preparation at English First, Cilegon. Those could be gotten from the subject selected English Teacher. Before the writers presented the data findings in this research. Firstly, the writer presented the subject profile.

The subject is an English Tutor has name Kaisan Rifki Al-ma'ruf who born on November 20 1992. He lives in Cibeber Cilegon. He graduated from Indonesia Univesity for $\mathrm{S} 1$, he graduated from Monash University in Australia for S2, he has many experiences, he ever taught in SMA Negeri 1 Bandung, and internship at PT Pos Indonesia, he always follows workshops about English programs, he teaches in Teaching Knowledge Test Younger Learner and TOEFL Preparation until now, he teaches basic in, he is able to treat the student with different kinds of characteristics from different provinces in her class, he has special methods for building students in speaking skills, he often asks students what is difficult in and asks the members to mention word one by one. $\mathrm{He}$ is able to make the members comfortable with their class, he is very welcome to all members, never forbid members who want to follow the class, and never distinguish between every member. he said every class has special characteristic, so it needs special strategies and methods to teach them more than effectively.

He said every tutor has a different method, but the point of material is the same and the development depends on the tutor. He said that teaching in other places is basically the same because at the class one of the member abilities is not far different. What makes it different is just also condition of atmosphere. He assumes that every teacher has problems in teaching, especially in TOEFL preparation. $\mathrm{He}$ always tries to make members comfortable with her when teaching in the class. He said be a tutor must be active, like a good speaker, good appearance is important, must be funny, and be the center of attention. He has a special trick to treat the member by his teaching variety by giving certain games and presentations. He is very kind, funny, humble, and easy going, as an English teacher; he tries to improve her teaching by following the workshop. 
This part presents research findings which the writers found in the field by doing observation and interview, It is related to the teachers' strategies in teaching TOEFL Preparation in EF Cilegon. After the writers investigated the teacher strategies in teaching TOEFL Preparation especially the listening section, finally the researcher got some data. The research findings were presented in the description of the bellows. According to the first question of interview, the teacher said that the strategy how to teach in the class, the strategy is the first time we have to prepare lesson plans, he learn at English camp before teaching the members used books as a source, and after that we apply and explain as student oriented, for difficult questions in listening part he uses simulation at the first, discussion for questions and answering, tips and tricks, media technology, communicative games and, motivation, simulation use computer based tests, in this test to measure how students are able to get the highest score of what students know about the types of questions tested after the simulation is finished

The second session is to dissect the TOEFL questions in discussion, so that students understand the mistakes in each problem worked especially in the next listening section, tips and tricks, in this session the teachers provide tips and tricks on the types of questions and how to fill in quickly and precisely, on the other hand the teacher also using media technology to teach this TOEFL preparation,

They use this media technology to make it easier to teach students a case of interactive videos, learning videos, problem questions, videos of American television broadcasters, this is an alternative so that students are easy and accustomed to working on problems and understanding in addition in his interview, he explained that he used interactive games in teaching so as not to be monotonous when learning and finally motivation, motivation must be built by the teacher so students are enthusiastic in taking the exam, the TOEFL test experience is the best experience to be able to share with students so that the students student struggle.

The data taken to the teacher ways in using the strategies in teaching English listening to support the student listening skill in TOEFL were taken from conducting interviews with the subject and having observation. The presentation of findings, in this part covers six kinds of listening section in TOEFL teaching strategies.

\section{a) Simulation}

The teacher use simulation TOEFL, When learning by simulation is described as an active process, caregivers reflect using theory and experience. . EF using 
software EF SET for Android or IOS, EF SET design by experts was developed for more than five year by leading scientists assessment. This simulation is reliable, easily accessible, EF SET goal is to make English proficiency test not only accurate, but also affordable, easy to use and always accessible in anytime.

\section{b) Discussions}

The writer found that discussion strategies can be used to improve student's question in TOEFL, discussions related to certain problem taught, the teacher allows students to question and answer in discussion about TOEFL, and how to take easy exam.

\section{c) Tips and tricks}

The teacher give a tips and tricks when student discussion, tip is a advice/help student to do something, or it can also be something that gives direction or suggestions for decisions or actions.

\section{d) ICT}

ICT (Information Communication and Technology) is media using the Media Education Technology such as computers; multimedia software is programmed in EF so that students can be actively involved and able to choose a variety of exercises and questions provided in the software. EF have EF Smart English is a free software application from the teaching \& training tools subcategory, part of education category, in TOEFL Preparation class, EF Smart English so many feature to help for listening skill like listening music with lyrics, watching scene movie, and quiz listening feature in this application.

\section{e) Games}

In EF offer a unique structure to complement traditional teaching strategies and infuse teaching with energy, spark innovative thinking and provide diversity in teaching methods. . Games will often act as learning triggers inducing lively discussion on learning concepts amongst students following game play. Examples of games used by EF are word match, Board Race, observe and remember, Miming games, Simon Says, Hangman, and ice breaking.

\section{f) Motivation}

Based on interview, teacher explain about student need motivation based experience how to well take exam, Motivation is an internal process that is one of the main factors that determines the success rate of student learning (Levpuscek \& Zupancic, 2008). Motivation is important in determining how many students will be learning from a learning activity or how much to absorb the information presented to them. Students are motivated to learn something will use higher cognitive 
processes in learning the material, so that students will absorb the material better.

\section{CONCLUSION}

Based on the discussion in this study, in the English First Cilegon, the teacher used various strategies in teaching listening section in TOEFL Preparation. The strategies that the teacher used in teaching TOEFL Preparation especially listening part were strategies (1) Simulation, discussion, give Tips and tricks, role play using media technology, using games interactive, give the motivation and experience. (2) the teacher used strategies to make the students' ability to take TOEFL be well is perceived is the key of success for assessment students in academic and future careers.

This study adopted qualitative research design and employed descriptive qualitative as a research method. the finding of this studies reveals the strategies used by some English Education Department of teachers in teaching speaking skills based on the research of interviews the writer gained some information related to the strategies of teaching TOEFL Preparation class. There are some statements for the student participant about teacher strategies in teaching TOEFL Preparation. They are: First, teacher strategies can improve confidence in good speaker and listener.
Second, teacher strategies can make students feel easier to take exam TOEFL. Third, the student often listening native speakers to understand can be enhanced. Fourth, the student can be more active how take TOEFL be well. the last, the student knows how to know type question in TOEFL especially listening section. Those strategies are used by the teacher to teach TOEFL Preparation class. From all of the strategies. The writer found sixth strategies used by the EF course Cilegon to teach TOEFL Preparation especially listening part.

\section{REFERENCES}

Aty, D. 2002. Introduction to Research in Education, sixth Edition, USA: Wadsworth Thomson Learning.

Cho \& Bridgeman, 2012; Relationship of TOEFL $i B T ®$ scores to academic performance: Some evidence from American universities.

DBall, D., \& Forzani, F. M. 2009. The work of teaching and the challenge for teacher education. Journal of teacher education, 60(5), 497-511

Educational Testing Service (ETS). 2017. About the TOEFL iBT® test. Available from https://www.ets.org/toefl/ibt/about [Accessed 08/12/2019]. 
Elvia Roza. 2019.The Challenges and

Strategies of Teachers in Teaching

TOEFL and IELTS Preparation,

https://journal.uir.ac.id/index.php/j

shmic/article/view/3067.

Erfani, S. S. 2014. An Investigation on the Attitudes of IELTS and TOEFL iBT Teachers: A Quantitative and Qualitative Washback Study. British Journal of Education, Society \& Behavioural Science, 4(1), 88-102.

Erfani, S. S. 2012. A comparative washback study of IELTS and TOEFL iBT on teaching and learning activities in preparation courses in the Iranian context. English Language Teaching, 5(8), 185.

Fakeye, D. O., \& Ogunsiji, Y. 2009. English language proficiency as a predictor of academic achievement among EFL students in Nigeria. European Journal of Scientific Research, 37(3), 490-495.

Feast, V. 2002. The impact of IELTS scores on performance at university. Doctoral dissertation. Flinders University.

Gear and Gear. 2008. Cambridge University Press; 3 edition, adventure house, NYC.

Harmer, Jeremy. 2007. How to Teach English. Harlow: Longman
Herreid 2006 Cases: Introducing Case Study Teaching Into Large Classrooms., Journal of college science teaching 36(2) · January 2006 "Clicker": Research Gate

H. C. Liou, J. E. Katchen, and H. Wang (Eds.) (2003), Lingua Tsing Hua : Teaching a Listening and Speaking Course with DVD Films: Can It Be Done? (pp. 221-236) Taipei: Crane http//mx.mthu.edu.tw/ katchen/pr ofessional/festschriff.htm accessed at 27 th June 2009

John M Bryson. 2004. Strategic Planning for Public and Non-profit Organizations A Guide to Strengthening and Sustaining Organizational Achievement, 3rd edition USA : Wiley online library.

Khan, S. Z. 2009. Imperialism of international tests: An EIL perspective. English as an international language Perspectives and pedagogical issues, 190-2056.

Miles and Huberman. 1998. logical analysis / matrix analysis qualitative data and analysis $2 n d$ edition. new bury park cal: SAGE publication

Naeimi,M. \& Chow,V.F. T. 2015. Vocabulary Acquisition using Direct and Indirect learning Strategies. English Language Teaching. Vol 8(10). Retrieved 
from

https://files.eric.ed.gov/fulltext/EJ1 079088.pdf

Mingyu Feng, Neil T Heffernan (2006). Informing teachers live about student learning: Reporting in the Assessment system volume 3: Publisher Old City Publishing Inc.

Oxford, R.L., 1990: Language Learning Strategies: What every Teacher should know. Boston: Heinle\&Heinle.

Recine. 2017. Strategy for Teaching TOEFL. Available from https://magoosh.com/toefl/2016/threeimportant-tips-for-teaching-the-toefl [Accessed 25/12/2019].

Richard Freeman\& Jeffrey Pelletier. 1990: The Impact of Industrial Relations Legislation on British Union Density: Wiley online library.

Richards, Jack C. 2008. Teaching Listening and Speaking from Theory to Practice. New York: Cambridge University Press. http://www.cambridge.org/elt/teac her-support/pdf/ RichardsTeaching-Listening-Speaking.pdf

Rita Wilson, Kalpana Aggarwal \& Milan Gowel., 2014: self-learning English Course with Activities book-7: Blackie eyt book.

Thomson, Kevin. 2005. BBC British council: Helping teen to Listen. http://www.teachingEnglish.org.uk /think/listen/teen_listen.shtml. [Accessed 25/12/2019].

W strong \& M. Perini. 2007.the strategic teacher the right research-based strategy for every lesson. Association for supervision and curriculum development. 
Volume 3 No. 2, August 2020

P-ISSN 2623-0062

Universitas Banten Jaya

E-ISSN 2622-9056 